\title{
Catenulispora acidiphila gen. nov., sp. nov., a novel, mycelium-forming actinomycete, and proposal of Catenulisporaceae fam. nov.
}

Correspondence

Stefano Donadio

stefano_donadio@libero.it

\author{
Elena Busti, ${ }^{1}$ Linda Cavaletti, ${ }^{1}$ Paolo Monciardini, ${ }^{1}$ Peter Schumann, ${ }^{2}$ \\ Manfred Rohde, ${ }^{3}$ Margherita Sosio ${ }^{1}$ and Stefano Donadio ${ }^{1} \dagger$ \\ ${ }^{1}$ Vicuron Pharmaceuticals, via Lepetit 34, 21040 Gerenzano, Italy \\ ${ }^{2} \mathrm{DSMZ}$ - Deutsche Sammlung von Mikroorganismen und Zellkulturen GmbH, \\ D-38124 Braunschweig, Germany \\ ${ }^{3} \mathrm{GBF}$ - Gesellschaft für Biotechnologische Forschung GmbH, D-38124 Braunschweig, \\ Germany
}

\begin{abstract}
A novel, Gram-positive bacterial strain was isolated from forest soil. Among species with validly published names, the 16S rRNA gene sequence is related most closely (approx. 93\% similarity) to that of Sporichthya polymorpha DSM $43042^{\top}$. However, differently from this species, it forms both vegetative and aerial mycelia. The aerial hyphae are straight to slightly flexuous, starting to septate to form chains of more than 20 cylindrical spores with a rugose surface. The strain is acidophilic, with a $\mathrm{pH}$ range for robust growth between 4.3 and 6.8 and an optimum around 6.0. The peptidoglycan type is A3 $\gamma$ LL-Dpm-Gly. The polar lipids are phosphatidylglycerol, diphosphatidylglycerol, phosphatidylinositol, phosphatidylinositol mannosides and two unknown phospholipids. Predominant menaquinones are $M K-9\left(\mathrm{H}_{6}\right)$ and $-9\left(\mathrm{H}_{4}\right)$, and iso- and anteiso-branched $\mathrm{C}_{16: 0}$ and $\mathrm{C}_{17: 0}$ are the main cellular fatty acids. The DNA $\mathrm{G}+\mathrm{C}$ content is $71.9 \mathrm{~mol} \%$. The distinct phylogenetic position and the unusual combination of chemotaxonomic characteristics justify the proposal of Catenulispora gen. nov., with the type species Catenulispora acidiphila sp. nov. (type strain, ID139908 ${ }^{\top}=\mathrm{DSM} 44928^{\top}=\mathrm{NRRL} B-24433^{\top}$ ).

Catenulisporaceae fam. nov. is also proposed.
\end{abstract}

The order Actinomycetales within the class Actinobacteria represents a large and diverse group of common soil inhabitants (McCarthy \& Williams, 1992) and antibiotic producers (Demain, 1998). Recent efforts in strain isolation (Sait et al., 2002; Joseph et al., 2003) and evidence from soil DNA (Monciardini et al., 2002) indicate the existence of novel taxa in the order Actinomycetales that may represent promising sources of novel metabolites (Bull et al., 2000; Donadio et al., 2002).

\section{Isolation and cultivation of strain ID139908 ${ }^{\top}$}

A soil sample collected from a wooded area in Gerenzano, Italy, was dried at $30{ }^{\circ} \mathrm{C}$ under vacuum for 7 days, resuspended in $18.2 \mathrm{mM}$ citric acid, $164 \mathrm{mM} \mathrm{Na}{ }_{2} \mathrm{HPO}_{4}$ buffer

tPresent address: KtedoGen, via Cav. Brusa 43, 21046 Malnate, Italy. Abbreviation: FESEM, field emission scanning electron microscopy.

The GenBank/EMBL/DDBJ accession number for the 16S rRNA gene sequence of strain ID139908 ${ }^{\top}$ is AJ865857.

Supplementary figures showing a FESEM image, polar lipid composition and phylogenetic position of strain ID139908 ${ }^{\top}$ are available in IJSEM Online.
( $\mathrm{pH} 7)$, and aliquots from serial dilutions were deposited onto GTV plates [GTV contains $500 \mathrm{ml}$ soil extract $1^{-1}$ (prepared by autoclaving $100 \mathrm{~g}$ fresh soil resuspended in $500 \mathrm{ml} \mathrm{H}_{2} \mathrm{O}$, followed by filtering through sterile gauze), $10 \mathrm{~g}_{\text {gellan gum ml}}{ }^{-1}, 3 \mathrm{mM} \mathrm{CaCl}_{2}$ (resulting $\mathrm{pH}, 5$ ) and was supplemented after autoclaving with $0 \cdot 1 \%(\mathrm{v} / \mathrm{v}) \mathrm{CMM}$ vitamin solution $\left(25 \mu \mathrm{g}\right.$ thiamin hydrochloride $\mathrm{ml}^{-1}$, $250 \mu \mathrm{g}$ calcium pantothenate $\mathrm{ml}^{-1}, 250 \mu \mathrm{g}$ nicotinic acid $\mathrm{ml}^{-1}, 500 \mu \mathrm{g}$ biotin $\mathrm{ml}^{-1}, 1 \cdot 25 \mathrm{mg}$ riboflavin $\mathrm{ml}^{-1}, 6 \mu \mathrm{g}$ vitamin $\mathrm{B}_{12} \mathrm{ml}^{-1}, 25 \mu \mathrm{g} p$-aminobenzoic acid ml ${ }^{-1}, 500 \mu \mathrm{g}$ folic acid ml $\mathrm{m}^{-1}$ and $500 \mu \mathrm{g}$ pyridoxal hydrochloride $\mathrm{ml}^{-1}$ ) and $50 \mu \mathrm{g}$ cycloheximide $\mathrm{ml}^{-1}$ ] and incubated at $28^{\circ} \mathrm{C}$. Seven strains, which appeared after an 8 week incubation, were related closely on the basis of their 16S rRNA gene sequences. One of these isolates was chosen for further studies and maintained on ISP2 agar (Shirling \& Gottlieb, 1966) adjusted to $\mathrm{pH} 5 \cdot 5-6 \cdot 0$ with $\mathrm{HCl}$, and was designated strain ID $139908^{\mathrm{T}}$.

\section{Morphology}

Morphology of aerial mass was examined directly on HSA5 agar plates [HSA5 consists of $0.5 \mathrm{~g}$ humic acid $1^{-1}$, 


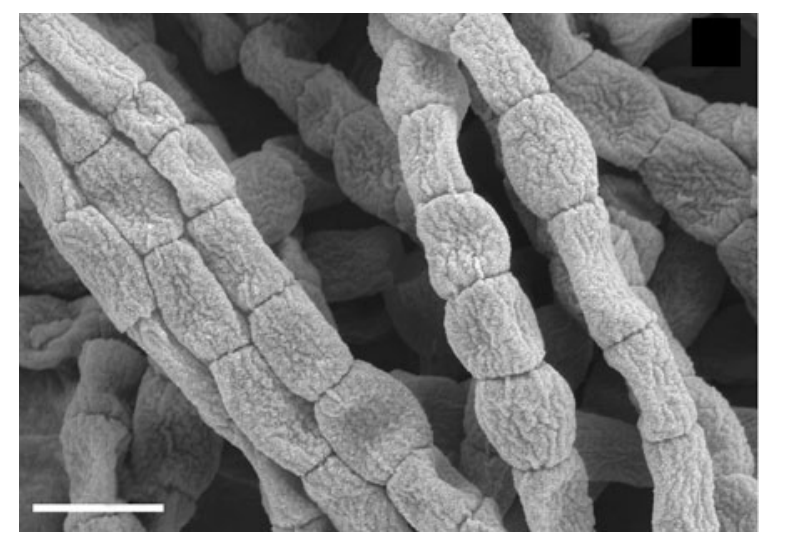

Fig. 1. FESEM of strain ID $139908^{\top}$ grown on HSA5 agar for 3 weeks at $28{ }^{\circ} \mathrm{C}$. Cylindrical arthrospores $(0.4-1 \cdot 0 \mu \mathrm{m}$ length by approx. $0.5 \mu \mathrm{m}$ diameter) with a rugose surface are visible. Collapsing of the central part of spore walls results in a wavy appearance of spore chains. Bar, $1 \mu \mathrm{m}$.

$1 \mathrm{mg} \mathrm{FeSO}{ }_{4} \cdot 7 \mathrm{H}_{2} \mathrm{O} 1^{-1}, 1 \mathrm{mg} \mathrm{MnCl}_{2} \cdot 4 \mathrm{H}_{2} \mathrm{O} 1^{-1}, 1 \mathrm{mg}$ $\mathrm{ZnSO}_{4} \cdot 7 \mathrm{H}_{2} \mathrm{O} \mathrm{l} \mathrm{l}^{-1}, 1 \mathrm{mg} \mathrm{NiSO}{ }_{4} \cdot 6 \mathrm{H}_{2} \mathrm{O} \mathrm{l}^{-1}, 10 \mathrm{mM} \mathrm{N}$ cyclohexyl-2-aminoethanesulfonic acid, $20 \mathrm{~g}$ agar $\mathrm{l}^{-1}$, adjusted to $\mathrm{pH} 5 \cdot 5$ and supplemented after autoclaving with $0 \cdot 1 \%(\mathrm{v} / \mathrm{v}) \mathrm{CMM}$ vitamin solution] after a 3-4 week incubation at $28^{\circ} \mathrm{C}$, under a light microscope equipped with a $\times 40$ long working distance objective (model ULWDCDPlan; Olympus) and fitted with a 3CCD camera (Sony). Strain $\mathrm{ID} 39908^{\mathrm{T}}$ forms a branched, non-fragmenting, vegetative mycelium and straight to slightly flexuous aerial hyphae. When drops of an $\mathrm{H}_{2} \mathrm{O}$ suspension of aerial mass from 3- or 4-week-old cultures were incubated at $28^{\circ} \mathrm{C}$ and checked under light microscopy at $30 \mathrm{~min}$ intervals for $2 \mathrm{~h}$, motile elements were not observed.

Field emission scanning electron microscopy (FESEM) was performed as described elsewhere (Hammerschmidt et al., 2005) by fixing samples of 3-week-old HSA5 agar cultures of strain ID $139908^{\mathrm{T}}$ with glutaraldehyde $(2 \%)$ and formaldehyde $(5 \%)$. FESEM revealed long filaments of aerial hyphae that showed marked septation, resulting in chains of more than 20 cylindrical arthrospores (see Supplementary Fig. S1, available in IJSEM Online). Spores show a rugose surface and are $0 \cdot 4-1 \cdot 0 \mu \mathrm{m}$ long, with a mean diameter of $0 \cdot 5 \mu \mathrm{m}$ (Fig. 1).

\section{Cultural and physiological characteristics}

The media used were those recommended by Shirling \& Gottlieb (1966), but acidified to pH 5.5-6.0 with $\mathrm{HCl}$. Inocula for cultural and physiological analyses were obtained by growing strain ID $139908^{\mathrm{T}}$ in ATSB medium (17 g casitone $^{-1}, 3$ g soytone $\mathrm{l}^{-1}, 2 \cdot 5$ g glucose $^{-1}, 10 \mathrm{mM}$ MES, adjusted to $\mathrm{pH} 5 \cdot 8$ with $\mathrm{HCl}$ ) for 1 week at $28^{\circ} \mathrm{C}$ on a rotary shaker at 200 r.p.m. Mycelium was washed with sterile $\mathrm{H}_{2} \mathrm{O}$ and then diluted to a suitable inoculum. Aliquots of the suspension were streaked in a cross-hatched manner onto the media used. Unless stated otherwise, all evaluations were made after 3 weeks incubation at $28^{\circ} \mathrm{C}$. The $\mathrm{pH}$ range for growth was determined by using ISP2 as basal medium, adjusted to the desired values with $\mathrm{HCl}$ or $\mathrm{NaOH}$. Temperature range for growth and $\mathrm{NaCl}$ and lysozyme tolerance were determined by using acidified (pH 5·5-6•0) ISP2 medium.

Table 1 shows the appearance of strain ID $139908^{\mathrm{T}}$ on various agar media. It grew well on most of the tested media, with production of brownish pigments and whitish aerial mass, turning to yellow/green with age. However, the brownish pigments were not observed in tyrosine-supplemented Suter medium (Suter, 1978), suggesting that they are not melanin-related. Strain ID139908 ${ }^{\mathrm{T}}$ grew well on media at initial $\mathrm{pH}$ between $4 \cdot 3$ and $6 \cdot 8$, with an optimum around $\mathrm{pH} 6 \cdot 0$, but scant growth was visible up to $\mathrm{pH} 7 \cdot 5$. This strain must thus be considered an acidophile. Optimal growth occurred between 22 and $28^{\circ} \mathrm{C}$ and measurable growth also occurred at 11 and $32^{\circ} \mathrm{C}$.

Strain ID $139908^{\mathrm{T}}$ could grow in the presence of up to $3 \%$ $(\mathrm{w} / \mathrm{v}) \mathrm{NaCl}$, albeit with a progressive reduction of pigmentation starting at $1 \% \mathrm{NaCl}$, and was resistant to at least $100 \mu \mathrm{g}$ lysozyme $\mathrm{ml}^{-1}$. Among carbon sources, as recorded

Table 1. Culture characteristics of strain ID $139908^{\top}$ after 3 weeks growth at $28^{\circ} \mathrm{C}$

All media were acidified to $\mathrm{pH} 5 \cdot 5-6 \cdot 0$.

\begin{tabular}{|llllll}
\hline Medium & Growth & \multicolumn{1}{c|}{ Reverse } & Aerial mass & Diffusible pigment \\
\hline ISP2 (yeast extract-malt extract agar) & $\begin{array}{c}\text { Abundant, } \\
\text { convolute }\end{array}$ & Dark brown/nutmeg (15E8) & Absent & Abundant, brown \\
& Good, thin & Cream to light brown (12C6) & Moderate, whitish & Good, brownish \\
ISP3 (oatmeal agar) & Good & Cream to light orange (11F6) & Absent & Good, brownish \\
ISP4 (inorganic salts-starch agar) & Good & Brown/sienna (5G12) & Scant, whitish & Abundant, light brown \\
ISP5 (glycerol-asparagine agar) & Absent & - & - & - \\
ISP6 (peptone-yeast extract-iron agar) & Abundant & Brown/mahogany (6L12) & Moderate, whitish & Abundant, brown \\
ISP7 (tyrosine agar) & & & & \\
\hline
\end{tabular}

${ }^{\star}$ Colour codes in parentheses are according to Maerz \& Paul (1950). 
on acidified ISP9 medium (Shirling \& Gottlieb, 1966), glucose, arabinose, xylose, mannitol, fructose and glycerol supported good growth, whereas no visible colonies were formed with sucrose, inositol, rhamnose or cellulose; scant growth was observed with raffinose. Aerobiosis-related properties were analysed on acidified ISP2 agar medium (plates were stored at $4{ }^{\circ} \mathrm{C}$ and evaporated before use) under an aerobic, microaerophilic (GasPack system with a Gas Generating kit for Campylobacter; Oxoid BR056A) or anaerobic atmosphere. Strain ID139908 ${ }^{\mathrm{T}}$ grew better under aerobic conditions, but reduced, non-pigmented growth was also obtained in microaerophilic and anaerobic atmospheres. The strain was positive for catalase (evaluated by mixing $0.8 \mathrm{ml}$ of a 1-week-old ATSB culture with $0.5 \mathrm{ml}$ freshly prepared $3 \%$ hydrogen peroxide), starch hydrolysis and gelatin liquefaction (Gottlieb, 1961), casein degradation [evaluated on acidified $1.5 \%(\mathrm{w} / \mathrm{v})$ skimmed-milk agar] and $\mathrm{H}_{2} \mathrm{~S}$ production (detected 2 days after inserting sterile lead acetate filter-paper strips into the necks of culture tubes containing acidified ISP6 medium). Strain ID $139908^{\mathrm{T}}$ was negative for nitrate reduction [evaluated after 3 and 7 days in ATSB medium supplemented with $2 \mathrm{~g} \mathrm{KNO}_{3} \mathrm{l}^{-1}$, using Bacto-Nitrite test strips (Difco) to reveal the presence of nitrites]. When $15 \mu \mathrm{l}$ of an antibiotic solution $\left(10 \mu \mathrm{g} \mathrm{ml}^{-1}\right)$ was spotted onto previously inoculated, acidified ISP2 plates, after 1 week at $28^{\circ} \mathrm{C}$, strain ID139908 ${ }^{\mathrm{T}}$ was found to be resistant to nalidixic acid, oxacillin, apramycin, daunomycin, GE2270, nisin, rifampicin and kanamycin, but sensitive to novobiocin, thiostrepton, A40926 and ramoplanin.

\section{Chemotaxonomic characteristics}

Freeze-dried biomass was obtained from a 1-week culture in ATSB medium. The peptidoglycan of strain ID139908 ${ }^{\mathrm{T}}$, analysed as described by Schleifer \& Kandler (1972) and modified according to Willems et al. (1997), contained LLdiaminopimelic acid (Dpm), glycine, glutamic acid and alanine. From the two-dimensional TLC pattern (data not shown) of peptides in the partial peptidoglycan hydrolysate (4 $\mathrm{M} \mathrm{HCl}, 100^{\circ} \mathrm{C}, 45 \mathrm{~min}$ ), the peptidoglycan was assigned to type A3 $\gamma$ LL-Dpm-Gly (A41.1 according to http://www. dsmz.de/species/murein.htm). Menaquinones [determined as described by Groth et al. (1997)] were MK-9 $\left(\mathrm{H}_{6}\right),-9\left(\mathrm{H}_{4}\right)$ and $-9\left(\mathrm{H}_{8}\right)$ (ratio of peak areas, $4 \cdot 5: 2 \cdot 8: 1 \cdot 0$, respectively). Whole-cell sugars [determined according to Staneck \& Roberts (1974)] contained large amounts of arabinose, together with xylose, ribose, rhamnose and glucose. The polar lipid pattern [determined according to Groth et al. (1997)] consists of phosphatidylglycerol, diphosphatidylglycerol, phosphatidylinositol, phosphatidylinositol mannosides and two unknown phospholipids (see Supplementary Fig. S2, available in IJSEM Online). The cellular fatty acid profile of strain ID $139908^{\mathrm{T}}$, analysed as described by Miller (1982), is composed of $\mathrm{i}_{-} \mathrm{C}_{16: 0}(47 \cdot 05 \%)$, ai- $\mathrm{C}_{17: 0}$ $(12 \cdot 73 \%), \mathrm{i}-\mathrm{C}_{17: 0}(5 \cdot 73 \%), \mathrm{C}_{16: 0}(5 \cdot 61 \%), \mathrm{i}-\mathrm{C}_{17: 1} \omega 9 \mathrm{c}$ $(4 \cdot 69 \%), \mathrm{i}-\mathrm{C}_{15: 0}(4 \cdot 26 \%), \mathrm{i}-\mathrm{C}_{16: 1} \quad(3.41 \%), \mathrm{C}_{16: 1} \omega 7 c$ $(3 \cdot 16 \%), \quad$ ai- $\mathrm{C}_{17: 1} \omega 9 c \quad(2 \cdot 84 \%), \quad$ ai- $\mathrm{C}_{15: 0} \quad(2 \cdot 25 \%)$,
$\mathrm{C}_{18: 1} \omega 9 c(1.43 \%), \mathrm{C}_{17: 0}$ cyclo $(1 \cdot 17 \%)$ and $\mathrm{C}_{17: 1} \omega 8 c$ $(1.06 \%)$ (fatty acids representing $<1.00 \%$ of the total are not reported). The DNA G $+\mathrm{C}$ content of strain ID139908 ${ }^{\mathrm{T}}$, determined according to Mesbah et al. (1989), is $71 \cdot 5 \mathrm{~mol} \%$.

Although strain ID $139908^{\mathrm{T}}$ and members of the family Streptomycetaceae share the presence of LL-diaminopimelic acid in the peptidoglycan and type $2 c$ fatty acids (sensu Kroppenstedt, 1985), their phospholipid and whole-cell sugar patterns, as well as the menaquinone composition, clearly differentiate them (Korn-Wendisch \& Kutzner, 1992; Zhang et al., 1997; Kim et al., 2003).

\section{Phylogenetic analysis}

The almost-complete 16S rRNA gene sequence for strain ID $139908^{\mathrm{T}}$ [1441 nt, corresponding to $93 \cdot 3 \%$ of the Escherichia coli sequence (Brosius et al., 1978)] was determined and compared with all GenBank entries as described previously (Monciardini et al., 2003). The partial 16S rRNA gene sequence of strain ID $139908^{\mathrm{T}}$ is $98 \cdot 6-99 \cdot 5 \%$ identical to those of the actinomycete strains Ellin 5093, 5062, 5034, 5119 and 5116 (Joseph et al., 2003), recently isolated from a pasture soil in Ellinbank, Australia, and $>99 \%$ identical to those of 'bacterium 12202' (GenBank accession no. AY639903) and 'Actinobacterium Aac30' (GenBank accession no. AB180773). No description of these strains has, to our knowledge, appeared in the literature. Among species with validly published names, the highest binary similarity values are with members of the suborder Frankineae, namely Sporichthya polymorpha DSM $43042^{\mathrm{T}}$ (93\%) and Geodermatophilus obscurus DSM 43161 (92.5\%). Representatives of several actinomycete lineages have $16 \mathrm{~S}$ rRNA gene sequence similarities to ID139908 ${ }^{\mathrm{T}}$ of between 91 and $92 \%$. Although strain ID $139908^{\mathrm{T}}$ clearly belongs to the order Actinomycetales, it does not seem to be affiliated to any of the described lineages within the order. Of the two described bacterial strains with the highest 16S rRNA gene sequence relatedness to strain ID $139908^{\mathrm{T}}$, S. polymorpha DSM $43042^{\mathrm{T}}$ also contains LL-diaminopimelic acid in its peptidoglycan, but the menaquinones differ, as strain ID $139908^{\mathrm{T}}$ has MK-9 $\left(\mathrm{H}_{6}\right)$ and $-9\left(\mathrm{H}_{4}\right)$ as major components, in contrast to DSM $43042^{\mathrm{T}}$, which has MK-9 $\left(\mathrm{H}_{6}\right)$ and $-9\left(\mathrm{H}_{8}\right)$ (Rainey et al., 1993). The fatty acid patterns also differentiate the two strains, as $S$. polymorpha is a $3 \mathrm{c}$ type, in contrast to ID $139908^{\mathrm{T}}$, which is of the 2c type (Kroppenstedt, 1985). Morphologically, the two strains are also completely different, as S. polymorpha exhibits a unique life cycle with the absence of a vegetative mycelium and the aerial mycelium dividing into rod-shaped to coccoid spores that are motile (Lechevalier \& Lechevalier, 1989). G. obscurus DSM 43161 is even more different from ID $139908^{\mathrm{T}}$, as the two strains do not share any chemotaxonomic markers (Goodfellow, 1989) and G. obscurus does not show the growth-cycle characteristics of filamentous actinomycetes (Luedemann \& Fonseca, 1989). Phenotypic characteristics of other members of the suborder Frankineae 
can be found elsewere (Tamura et al., 1998; Maszenan et al., 2005).

When the sequence of strain ID $139908^{\mathrm{T}}$ was aligned with those deposited for the Ellinbank isolates and with those obtained from similar strains isolated in our laboratory, we could identify the signature nucleotides of the order Actinomycetales with the exception of position 449, where a $\mathrm{C}$ is found instead of the A proposed for the order (Stackebrandt et al., 1997). However, we could not find the signature nucleotide pattern of any of the other described suborders (Stackebrandt et al., 1997). Of the six signatures described for the suborder Frankineae, three are not found in ID139908 ${ }^{\mathrm{T}}$ and related strains, namely $141: 222$ (A-U instead of $\mathrm{G}-\mathrm{C}$ ), 371:390 (A-U instead of $\mathrm{G}-\mathrm{C}$ ) and 1003 : 1037 (G-C instead of $G-G)$.

The 16S rRNA gene sequence of strain ID $139908^{\mathrm{T}}$ was aligned with those of the type species of the major actinomycete lineages and analysed as described previously (Monciardini et al., 2003). The resulting phylogenetic tree is shown in Fig. 2. As no obvious relatives of the novel strain could be identified, we included in the analysis representatives of different families of the various suborders, with a particular focus on filamentous actinomycetes. Strain ID $139908^{\mathrm{T}}$, together with the Ellinbank isolates (Joseph et al., 2003), forms a coherent clade within the Actinomycetales lineage, clearly distinguished from other described strains. Although the closest relatives of the novel lineage appear to be members of the suborder Frankineae, bootstrap values are too low to allow definitive phylogenetic placement within this suborder, as also suggested by the low pairwise identity of $16 \mathrm{~S}$ rRNA gene sequences and by the differences in the pattern of signature nucleotides. A phylogenetic tree obtained from the alignment of the 16S rRNA gene sequences of representatives of the described families of the suborder Frankineae (Tamura et al., 1998; Maszenan et al., 2005) with those of strain ID $139908^{\mathrm{T}}$ and related strains further confirms that the two lineages are independent (see Supplementary Fig. S3, available in IJSEM Online). Additional phylogenetic analyses, performed with different sequences and treeing methods, confirm the high divergence of ID $139908^{\mathrm{T}}$ and related sequences from representatives of described families of the Actinomycetales (not shown). Altogether, phylogenetic data indicate that strain ID139908 ${ }^{\mathrm{T}}$ is sufficiently divergent from known bacterial species as to be described as being representative of a novel genus. In

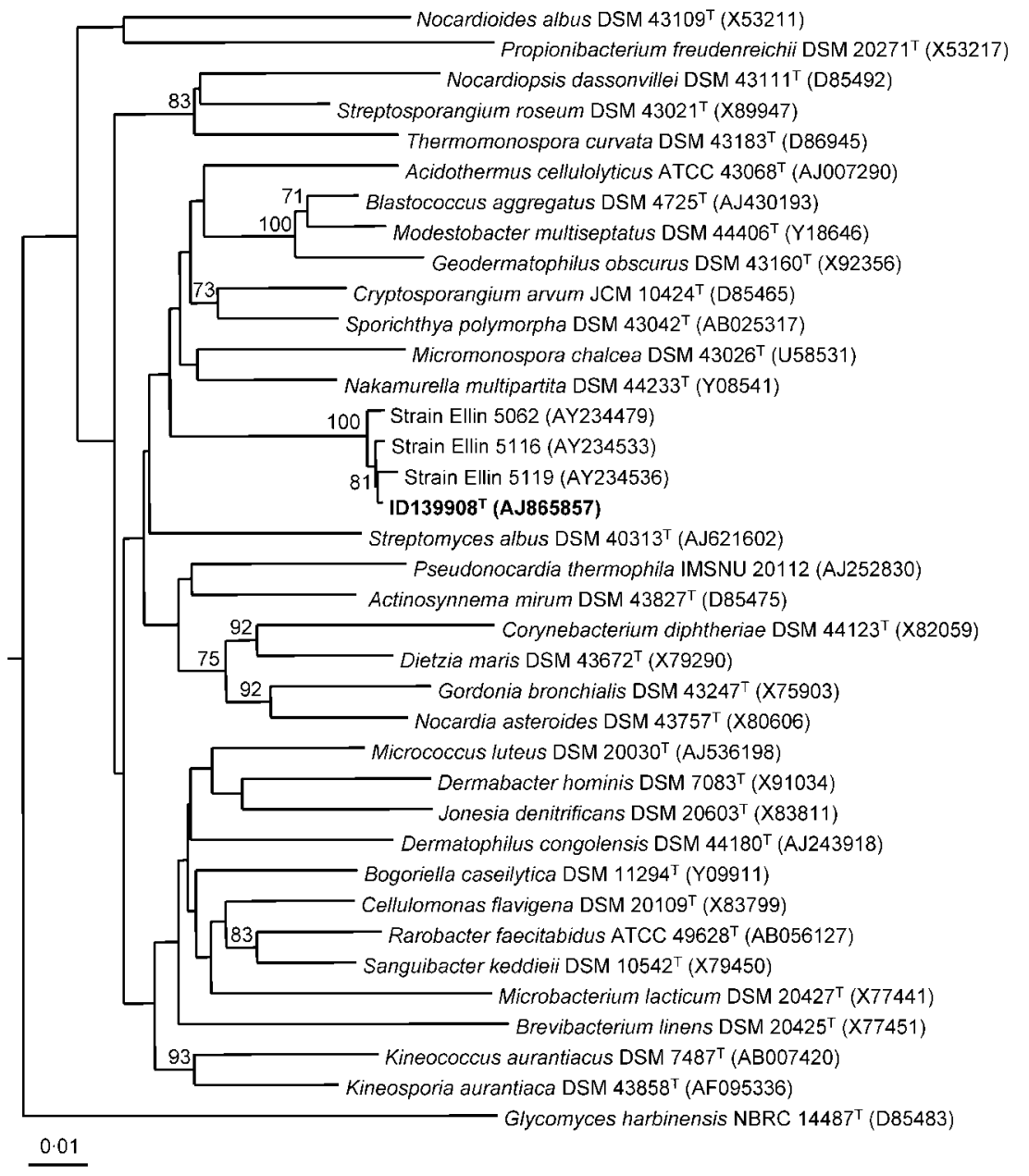

Fig. 2. Neighbour-joining tree based on 1324 aligned positions within the 16S rRNA gene. GenBank accession numbers for the sequences are in parentheses. The tree was rooted by using the $16 \mathrm{~S}$ rRNA gene sequence of Bifidobacterium bifidum NBRC $14252^{\top}$ (GenBank accession no. S83624). Numbers at nodes are bootstrap values based on 100 resamplings; only values $>65$ are shown. Bar, 1 inferred nucleotide substitution per 100 nt. 
addition, these data support the hypothesis that strain ID $139908^{\mathrm{T}}$, along with the closely related Ellinbank strains, represents a novel family within the order Actinomycetales. Thus, it is proposed that Catenulispora gen. nov. should be established in order to harbour strain ID $139908^{\mathrm{T}}$. Following the guidelines for the affiliation to higher hierarchical taxa in the class Actinobacteria proposed by Stackebrandt et al. (1997), which base the clustering solely on phylogenetic relationships, we propose the description of Catenulisporaceae fam. nov. to accommodate the proposed genus Catenulispora.

\section{Description of Catenulisporaceae fam. nov.}

(Ca.te.nu.li.spo.ra'ce.ae. N.L. fem. n. Catenulispora type genus of the family; -aceae ending to denote a family; N.L. fem. pl. n. Catenulisporaceae the Catenulispora family).

The family contains the type genus Catenulispora. The pattern of 16S rRNA gene signatures consists of nt $127: 234$ (G-C), 129:232 (U-A), 449 (C), $580: 761$ (U-A), 586: 755 (U-A), $591: 648(\mathrm{C}-\mathrm{G}), 824: 876(\mathrm{~A}-\mathrm{U}), 825: 875(\mathrm{~A}-\mathrm{U})$, $834: 852$ (G-U), 838:848 (U-G), 952:1229 (U-A), 999: 1041 (U-U) and 1000: $1040(\mathrm{U}-\mathrm{U})$. A phylogenetic analysis is presented in this study.

\section{Description of Catenulispora gen. nov.}

Catenulispora (Ca.te.nu.li.spo'ra. L. fem. n. catenula small chain; Gr. fem. n. spora seed; N.L. fem. n. Catenulispora a thin chain of spores).

Gram-positive, acidophilic, non-acid-fast, aerobic organisms forming branching hyphae. Non-fragmentary vegetative mycelium and aerial hyphae starting to septate in chains of cylindrical arthrospores are produced. Motile elements are not produced. Peptidoglycan contains LL-diaminopimelic acid, glycine, glutamic acid and alanine. Glucose, xylose, ribose, rhamnose and arabinose (the latter in large amounts) are detected as whole-cell sugars. i- $\mathrm{C}_{16: 0}$ and ai- $\mathrm{C}_{17: 0}$ are present as major cellular fatty acids. Menaquinones MK-9 $\left(\mathrm{H}_{6}\right)$ and MK-9 $\left(\mathrm{H}_{4}\right)$ are predominant, but MK$9\left(\mathrm{H}_{8}\right)$ is also detected. Polar lipids are phosphatidylglycerol, diphosphatidylglycerol, phosphatidylinositol, phosphatidylinositol mannosides and two unknown phospholipids. The $\mathrm{G}+\mathrm{C}$ content of the DNA is $71 \mathrm{~mol} \%$. The type species is Catenulispora acidiphila.

\section{Description of Catenulispora acidiphila sp. nov.}

Catenulispora acidiphila (a.ci.di'phi.la. N.L. neut. n. acidum acid; Gr. adj. philos loving; N.L. fem. adj. acidiphila acid-loving).

Chemotaxonomic and general characteristics are the same as given above for the genus. Acidophilic: grows well in a $\mathrm{pH}$ range from $4 \cdot 3$ to $6 \cdot 8$, optimal around $6 \cdot 0$. Mesophilic: best growth occurs at $22-28^{\circ} \mathrm{C}$, but significant growth can also be observed at 11 and $37^{\circ} \mathrm{C}$; no growth occurs at 4 or $40^{\circ} \mathrm{C}$. Aerial hyphae are relatively short, straight to flexuous and produce chains of more than 20 cylindrical arthrospores. Spores have a length in the range $0 \cdot 4-1.0 \mu \mathrm{m}$ and a mean diameter of around $0.5 \mu \mathrm{m}$. Spore surface is rugose. The organism grows well on various media, better on acidic yeast extract-malt extract agar and acidic tyrosine agar. In general, the soluble pigments produced by the type strain, as well as the vegetative mycelium, are brownish, whilst the aerial mass is whitish, turning to yellow/green with ageing. Brown mahogany soluble pigment is produced on tyrosine agar; no pigmentation is observed on tyrosine-supplemented Suter synthetic medium. $\mathrm{H}_{2} \mathrm{~S}$ is produced. Nitrates are not reduced. Starch and casein are hydrolysed. Gelatin is liquefied. Catalase-positive. $\mathrm{Up}$ to $3 \%(\mathrm{w} / \mathrm{v}) \mathrm{NaCl}$ is tolerated, as well as $100 \mu \mathrm{g}$ lysozyme $\mathrm{ml}^{-1}$. Glucose, arabinose, xylose, mannitol, fructose and glycerol are utilized, whereas sucrose, inositol, rhamnose and cellulose are not. Resistant to nalidixic acid, oxacillin, apramycin, daunomycin, GE2270, nisin, rifampicin and kanamycin at $10 \mu \mathrm{g} \mathrm{ml}^{-1}$, but sensitive to the same concentration of novobiocin, thiostrepton, A40926 and ramoplanin. The G $+\mathrm{C}$ content of the DNA is $71.5 \mathrm{~mol} \%$.

The type strain, ID $139908^{\mathrm{T}} \quad\left(=\mathrm{DSM} \quad 44928^{\mathrm{T}}=\mathrm{NRRL}\right.$ B- $\left.24433^{\mathrm{T}}\right)$, was isolated from temperate forest soil.

\section{Acknowledgements}

We are grateful to Ruggiero Bamonte for his contribution.

\section{References}

Brosius, J., Palmer, M. L., Kennedy, P. J. \& Noller, H. F. (1978). Complete nucleotide sequence of a $16 \mathrm{~S}$ ribosomal RNA gene from Escherichia coli. Proc Natl Acad Sci U S A 75, 4801-4805.

Bull, A. T., Ward, A. C. \& Goodfellow, M. (2000). Search and discovery strategies for biotechnology: the paradigm shift. Microbiol Mol Biol Rev 64, 573-606.

Demain, A. L. (1998). Microbial natural products: alive and well in 1998. Nat Biotechnol 16, 3-4.

Donadio, S., Monciardini, P., Alduina, R., Mazza, P., Chiocchini, C., Cavaletti, L., Sosio, M. \& Puglia, A. M. (2002). Microbial technologies for the discovery of novel bioactive metabolites. J Biotechnol 99, 187-198.

Goodfellow, M. (1989). Suprageneric classification of actinomycetes. In Bergey's Manual of Systematic Bacteriology, vol. 4, pp. 2333-2339. Edited by S. T. Williams, M. E. Sharpe \& J. G. Holt. Baltimore: Williams \& Wilkins.

Gottlieb, D. (1961). An evaluation of criteria and procedures used in the description and characterization of the streptomycetes. Appl Microbiol 9, 55-65.

Groth, I., Schumann, P., Rainey, F. A., Martin, K., Schuetze, B. \& Augsten, K. (1997). Bogoriella caseilytica gen. nov., sp. nov., a new alkaliphilic actinomycete from a soda lake in Africa. Int $J$ Syst Bacteriol 47, 788-794.

Hammerschmidt, S., Wolff, S., Hocke, A., Rosseau, S., Müller, E. \& Rohde, M. (2005). Illustration of pneumococcal polysaccharide capsule during adherence and invasion of epithelial cells. Infect Immun 73, 4653-4667. 
Joseph, S. J., Hugenholtz, P., Sangwan, P., Osborne, C. A. \& Janssen, P. H. (2003). Laboratory cultivation of widespread and previously uncultured soil bacteria. Appl Environ Microbiol 69, $7210-7215$

Kim, S. B., Lonsdale, J., Seong, C.-N. \& Goodfellow, M. (2003). Streptacidiphilus gen. nov., acidophilic actinomycetes with wall chemotype I and emendation of the family Streptomycetaceae (Waksman and Henrici $(1943)^{\mathrm{AL}}$ ) emend. Rainey et al. 1997. Antonie van Leeuwenhoek 83, 107-116.

Korn-Wendisch, F. \& Kutzner, H. J. (1992). The family Streptomycetaceae. In The Prokaryotes, 2nd edn, vol. 1, pp. 921-995. Edited by A. Balows, H. G. Trüper, M. Dworkin, W. Harder \& K. H. Schleifer. Heidelberg: Springer.

Kroppenstedt, R. M. (1985). Fatty acid and menaquinone analysis of actinomycetes and related organisms. In Chemical Methods in Bacterial Systematics, pp. 173-199. Edited by M. Goodfellow \& D. E. Minnikin. London: Academic Press.

Lechevalier, M. P. \& Lechevalier, H. A. (1989). Genus Sporichthya Lechevalier, Lechevalier and Holbert 1968, 279 ${ }^{\mathrm{AL}}$. In Bergey's Manual of Systematic Bacteriology, vol. 4, pp. 2507-2508. Edited by S. T. Williams, M. E. Sharpe \& J. G. Holt. Baltimore: Williams \& Wilkins.

Luedemann, G. M. \& Fonseca, A. F. (1989). Genus Geodermatophilus Luedemann 1968, $1857^{\mathrm{AL}}$. In Bergey's Manual of Systematic Bacterio$\log y$, vol. 4, pp. 2406-2409. Edited by S. T. Williams, M. E. Sharpe \& J. G. Holt. Baltimore: Williams \& Wilkins.

Maerz, A. \& Paul, M. R. (1950). Dictionary of Color, 2nd edn. New York: McGraw-Hill.

Maszenan, A. M., Tay, J.-H., Schumann, P., Jiang, H.-L. \& Tay, S. T.-L. (2005). Quadrisphaera granulorum gen. nov., sp. nov., a Gram-positive polyphosphate-accumulating coccus in tetrads or aggregates isolated from aerobic granules. Int J Syst Evol Microbiol 55, 1771-1777.

McCarthy, A. J. \& Williams, S. T. (1992). Actinomycetes as agents of biodegradation in the environment - a review. Gene 115, 189-192.

Mesbah, M., Premachandran, U. \& Whitman, W. B. (1989). Precise measurement of the $\mathrm{G}+\mathrm{C}$ content of deoxyribonucleic acid by high-performance liquid chromatography. Int J Syst Bacteriol 39, 159-167.

Miller, L. T. (1982). Single derivatization method for routine analysis of bacterial whole-cell fatty acid methyl esters, including hydroxy acids. J Clin Microbiol 16, 584-586.
Monciardini, P., Sosio, M., Cavaletti, L., Chiocchini, C. \& Donadio, S. (2002). New PCR primers for the selective amplification of $16 \mathrm{~S}$ rDNA from different groups of actinomycetes. FEMS Microbiol Ecol 42, 419-429.

Monciardini, P., Cavaletti, L., Schumann, P., Rohde, M. \& Donadio, S. (2003). Conexibacter woesei gen. nov., sp. nov., a novel representative of a deep evolutionary line of descent within the class Actinobacteria. Int J Syst Evol Microbiol 53, 569-576.

Rainey, F. A., Schumann, P., Prauser, H., Toalster, R. \& Stackebrandt, E. (1993). Sporichthya polymorpha represents a novel line of descent within the order Actinomycetales. FEMS Microbiol Lett 109, 263-267.

Sait, M., Hugenholtz, P. \& Janssen, P. H. (2002). Cultivation of globally distributed soil bacteria from phylogenetic lineages previously only detected in cultivation-independent surveys. Environ Microbiol 4, 654-666.

Schleifer, K. H. \& Kandler, O. (1972). Peptidoglycan types of bacterial cell walls and their taxonomic implications. Bacteriol Rev 36, 407-477.

Shirling, E. B. \& Gottlieb, D. (1966). Methods for characterization of Streptomyces species. Int J Syst Bacteriol 16, 313-340.

Stackebrandt, E., Rainey, F. A. \& Ward-Rainey, N. L. (1997). Proposal for a new hierarchic classification system, Actinobacteria classis nov. Int J Syst Bacteriol 47, 479-491.

Staneck, J. L. \& Roberts, G. D. (1974). Simplified approach to identification of aerobic actinomycetes by thin-layer chromatography. Appl Microbiol 28, 226-231.

Suter, M. A. (1978). Isolierung von Melanin-negativen Mutanten aus Streptomyces glaucescens. $\mathrm{PhD}$ thesis, Eidgenössische Technische Hochschule Zürich, Switzerland (no. 6276) (in German).

Tamura, T., Hayakawa, M. \& Hatano, K. (1998). A new genus of the order Actinomycetales, Cryptosporangium gen. nov., with descriptions of Cryptosporangium arvum sp. nov. and Cryptosporangium japonicum sp. nov. Int J Syst Bacteriol 48, 995-1005.

Willems, A., Moore, W. E. C., Weiss, N. \& Collins, M. D. (1997). Phenotypic and phylogenetic characterization of some Eubacteriumlike isolates containing a novel type B wall murein from human feces: description of Holdemania filiformis gen. nov., sp. nov. Int J Syst Bacteriol 47, 1201-1204.

Zhang, Z., Wang, Y. \& Ruan, J. (1997). A proposal to revive the genus Kitasatospora (Omura, Takahashi, Iwai, and Tanaka 1982). Int J Syst Bacteriol 47, 1048-1054. 